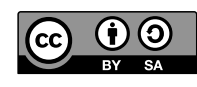

DOI: $10.4312 / \mathrm{mz} \cdot 57.1 .149-175$

UDK 78.071.1(510)Zhao:321.64:321.74

\title{
Cultural Revolution and Political Ambivalence in Zhao Xiaosheng's Two Ballades for Piano Solo
}

\author{
Xue Ke, ${ }^{a}$ Loo Fung Ying, \\ Loo Fung Chiat, ${ }^{c}$ Wang Xiaohang ${ }^{\mathrm{d}}$ \\ ${ }^{a}$ Beibu Gulf University, China \\ ${ }^{\mathrm{b}}$ University of Malaya \\ 'Universiti Putra Malaysia

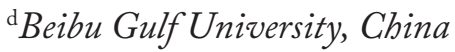

\begin{abstract}
The ascendancy of China's Cultural Revolution led to a purge of the rightists, including musicians. This article unveils composer Zhao Xiaosheng's emotional entanglement of fear and suppressed hostility toward the revolution, reflected in the political and artistic ambivalence in his two ballades for solo piano composed after his father's death.
\end{abstract}

Keywords: Zhao Xiaosheng, Cultural Revolution, China, new wave composer, piano solo works, Communism

\section{IZVLEČEK}

Prevlada kitajske kulturne revolucije je privedla tudi do čistk desničarjev, vključno z glasbeniki. Članek odstira strah in potlačeno sovražnost skladatelja Žaa Šaošenga do revolucije. Oboje se odraža v politični in umetniški ambivalenci njegovih dveh balad za klavir, ki ju je napisal po smrti svojega očeta.

Ključne besede: Žao Šaošeng, kulturna revolucija, Kitajska, skladatelj novega vala, solistična klavirska dela, komunizem

* This research was supported by University Malaya Research Grant RP038B-17HNE as well as Humanity and Social Science Youth Foundation of Ministry of Education of China Grant (19YJC760133). 


\section{Introduction}

The decade-long Cultural Revolution in China (1966-1976) under the authoritarian leadership of the Communist Party of China's Chairman Mao Zedong's (毛泽东) followed the principles of socialism and Marxism. This resulted in a rise of fanaticism in China, created chaos in the society, and led to the purges of the rightists, especially the intellectuals. ${ }^{1}$ In addition, the Cultural Revolution led to the formation of the radical and factional "Gang of Four (四 人帮)" 2 and Red Guards (红卫兵). They became major forces that eliminated any sign of the bourgeoisie, and of the "Four Olds" or "feudal culture." ${ }^{3}$ Due to the brutal censorship exercised by the Red Guards, tolerance and liberalism in the area of art came to a halt. ${ }^{4}$ During the revolutionary period, expressing a fondness for Western art music was considered as a mark of the bourgeoisie and this fondness was likened to a tumor. ${ }^{5}$ There was resentment toward Western music trained musicians such as Fou Tsong, whose father was a professor and translator of French literature. Fou Tsong was devastated and angry when both his parents committed suicide at the start of the revolution. He expressed resentment towards his country by saying that: "[Mao's rule is] a form of fascism, because it is totalitarian and hypocritical." He further added that the Chinese leaders were "full of lies."

During the revolutionary period, Western art music was generally considered as elite music. It was considered as the type of music that belonged to the bourgeoisie. However, contradictorily, the Communist Party members and followers considered that following the West was a sign of modernity, but they accordingly shunned Western art, music, and thought. The latter led to the survival of the use of Western art music elements and music instruments

1 Further details in: Felix Wemheuer, A Social History of Maoist China: Conflict and Change, 19491976 (New York: Cambridge University Press, 2019).

2 The "Gang of Four" is a political faction that existed in the period of the Cultural Revolution, which was led by Jiang Qing (Mao's wife) and three other officials: Zhang Chunqiao, Yao Wenyuan, and Wang Hongwen. The appellation of Gang of Four was first used in 1974 when they criticized Zhou Enlai and Deng Xiaoping through the campaign of 'Criticize Lin Biao and Confucius'. However, the members of the Gang of Four turned the Cultural Revolution into a "dark night," "raging blood," or "a savage beast." Michael Sullivan, "The Politics of Conflict and Compromise," in China Since the 'Gang of Four', ed. Bill Brugger (London: Routledge, 1980).

3 The Red Guards were Chinese urban youth. Under Mao's directives, they persecuted the bourgeoisie intellectuals and teachers, gained control of schools, and destroyed cultural icons and arts. Larry E. Sullivan, The Sage Glossary of the Social and Behavioral Sciences (California: Sage Publications, 2009), 127. The "Four Olds" were old customs, culture, habits, and ideas. Further details in: Richard Curt Kraus, "Policy Case Study: The Arts," in Politics in China: An Introduction, ed. William Joseph (New York: Oxford University Press, 2019), 373.

4 Lincoln Cushing and Ann Tompkins, Chinese Posters: Art from the Great Proletarian Cultural Revolution (San Francisco: Chronicle Books LLC, 2007).

5 Barbara Mittler, "Cultural Revolution Model Works and the Politics of Modernization in China: An Analysis of 'Taking Tiger Mountain by Strategy'," The World of Music 45, no. 2 (2003): 53-81.

6 Lek Hor Tan, "Fou Tsong: I Wept for China," Index on Censorship 8, no. 89 (2007): 21. 
during the Cultural Revolution. ${ }^{7}$ In describing its irony, political scientist Richard Kraus explained that "the piano was likened to a coffin, in which notes rattled about like the bones of the bourgeoisie." However, the piano was also perceived as a departure from Chinese traditional culture or one of the "Four Olds," and the radical leader Jiang Qing (Mao's wife) "had a soft spot in her heart for pianos, which she helped save from Red Guard destruction." "The examples of works produced under the supervision of Jiang Qing are Huanghe (Yellow River Piano Concerto) and the revolutionary symphony, Zhiqu Weibushan (Taking Tiger Mountain by Strategy). ${ }^{9}$ These works served as a coalescent between Western art music form and China's political propaganda during the period of the Cultural Revolution. Jiang Qing also transformed the traditional Peking opera into the Model Opera or Yangbanxi (样板戏) using a Western heptatonic scale and an accompaniment of Chinese traditional instruments with Western orchestra instruments. This form further became the legitimate musical form that conformed to Mao's doctrine. ${ }^{10}$ On the other hand, instrumental or vocal music genre served as a panegyric of socialism and Maoism, or as an accompaniment to the Model Opera. Thus, the musicians' creative output needed to be approved by the Union of Chinese Musicians ${ }^{11}$ and their career prospects depended on following the new revolutionary musical model with legitimate musical form and style. ${ }^{12}$ Placing such restrictions on the composition of music was advocated by Mao's in the following statement: "there is in fact no such thing as art for art's sake, art that stands above classes, art that is detached from or independent of politics." ${ }^{13}$

During the revolution, musicians and other intellectuals were further intimidated by Mao's propaganda tool - dazibao or big-character posters displayed by the Red Guards at public spaces, schools, and universities. These posters condemned past educational styles, declared charges and issued reprimands to "rebels." ${ }^{14}$ In line with Mao's beliefs, music teachers and professors

7 Sheila Melvin and Jindong Cai, Rhapsody in Red: How Western Classical Music became Chinese (New York: Algora Publishing, 2004), 301.

8 Richard Curt Kraus, Pianos \& Politics in China: Middle-Class Ambitions and the Struggle over Western Music (New York and Oxford: Oxford University Press, 1989), vii.

9 Ching-Chih Liu, A Critical History of Nerw Music in China (Hong Kong: The Chinese University Press, 2010), 457.

10 Don Michael Randel, The Harvard Dictionary of Music (Cambridge, Massachusetts: The Belknap Press of Harvard University Press, 2003), 265.

11 Ibid.

12 Rachel J. Maine, "Comparative Repression: Examples of Musical Repression by Hitler, Stalin, and Mao" (Master thesis, Baylor University, 2006), 33.

13 Zedong Mao, Quotations from Chairman Mao Tse-Tung and Other Works [Little Red Book] (Beijing: Foreign Language Press, 1966), 299.

14 Xing Lu, Rhetoric of the Chinese Cultural Revolution: The Impact on Chinese Thought, Culture, and Communication (South Carolina: University of South Carolina, 2004), 73-96. Dazibao is a large-size poster with large hand-written Chinese calligraphy that was used during the Cultural 
in schools and conservatories were given the derogatory label of "criminals" for either being "capitalist roaders" or belonging to the bourgeoisie. ${ }^{15}$ This belief of Mao led to an anti-leftist purge and denouncement of musicians, professors, and composers. During an interview, composer Zhao Xiaosheng (赵晓生), recalled that his father was one of the eleven music professors of Shanghai Conservatory of Music whose lives were taken during the period of the Cultural Revolution and that it was this incident that led to his composition of the piano solo Ballade in Db Major. ${ }^{16}$

Mao's reeducation program included sending younger musicians to the camp of Laogai (劳改, thought reform through labor). ${ }^{17}$ This led to a "new wave" of Chinese composers, who underwent the rustication program (上山下 乡运动, up to the mountains and down to the countryside) as part of the Laogai system. Their obligatory participation in this program led to a long immersion in the selected fields including underprivileged society, rural living, farming and fishing. This evoked a change in the Chinese composers' poiesis, ${ }^{18}$ a term used by the semiologist Jean Molino to refer to the first step of a creation. The "new wave" composers presented a musical style that incorporated Chinese traditional and folk music elements, an obvious influence of their experiences through the rustication program. Subsequently, they were then enrolled and trained at music conservatories after the National College Entrance Examination (高考) resumed, and tried to express individuality in their works. ${ }^{19}$

The impact of the revolution on China's musical development attracted considerable attention of scholars such as $\mathrm{Xu}$, Judd, Yung, Mittler and Lu. ${ }^{20}$

Revolution. It also became a form of practice of Chinese calligraphy in schools as part of the Chinese Yuwen curriculum in 1966. See also Cynthia B. Leung and Yiping Wang, "Influences of the Cultural Revolution on Chinese Literacy Instruction," in Perspectives on Teaching and Learning Chinese Literacy in China, eds. Cynthia B. Leung and Jiening Ruan (London: Springer, 2012), 49-60.

15 Angang Hu, Mao and the Cultural Revolution: Mao's Motivation and Strategy (Honolulu, Hong Kong, Beijing and Singapore: Silkroad Press, 2017); Hong-Yung Lee, The Politics of the Chinese Cultural Revolution: A Case Study (Los Angeles and London: University of California Press, 1978).

16 Xiaosheng Zhao, interview, October 31, 2016, Shanghai, China.

17 Laikwan Pang, Paul Clark, and Tsan Huang Tsai, Listening to China's Cultural Revolution: Music, Politics, and Cultural Continuities (Hampshire: Palgrave MacMillan, 2016), 72.

18 See Guerino Mazzola, Maria Mannone, and Yan Pang, All About Music: The Complete Ontology; Realities, Semiotics, Communication, and Embodiment (Cham: Springer, 2016).

19 Anguo Wang, "Xinchao Yinyue - Yiduan Teding de Lishi Wenhua Guocheng," ["New Wave Music - A Special Historical and Cultural Process"], Literature \& Art Studies, no. 1 (1988): 66.

20 See Guohui Xu, Model Operas \& the Politics of The Great Proletarian Cultural Revolution (Taibei: Showwe Publisher, 2019); Ellen R. Judd, "Perspective Dramatic Theory of Cultural Revolution," in Drama in the People's Republic, eds. Constantine Tung and Colin Mackerras (Albany: State University of New York, 1987), 94-118; Bell Yung, "Model Opera as Model from Shajiabang to Sagaban," in Popular Chinese Literature and Performing Arts in the People's Republic of China 1949-1979, ed. Bonnie S. McDougall (Berkeley: University of California Press, 1984), 144-164; Mittler, "Cultural Revolution Model Works and the Politics of Modernization in China," 53-81; 
Many researchers focused primarily on political factions and the Model Operas. For example, Chi and Moskowitz studied the emblematic revolutionary music and dance epic East is Red and discussed how it later became a popular national song throughout the country. ${ }^{21} \mathrm{Lu}$ looked into the anthems and quotation songs of Chairman Mao. ${ }^{22}$ Songs such as Sailing the Sea Depends on the Helmsman, There will be no New China without the Communist Party, Make up Your Mind, Rebellion is Justified are the representative examples of quotation songs. An obvious worship to Mao is evident from these in the rhetorical use of 'he' in the song text of There will be no New China without the Communist Party, that either praises Mao or the Communist Party led by Mao. ${ }^{23}$ The literature on piano music mainly focused on Huanghe as the representative revolutionary model work..$^{24}$ On the other hand, Kraus explored in detail the contested role of the piano in the revolution with cases of three virtuoso pianists: Fu Cong (傅聪), Yin Chengzong (殷承宗), and Liu Shikun (刘诗昆).

New piano solo works did appear in the middle and later years of the Cultural Revolution, but they were concomitant with fear. The composers' infighting allegiance to the Communist Party's model works eviscerated the patriotic intention in their works to a certain extent. ${ }^{25}$ Examples of such works are Huang Anlun's (黄安伦) Overture and Dance suite and Zhao Xiaosheng's six études and two ballades composed between the years 1973-1976. The traumatic fear of being reprimanded resulted in resistance to music composition that revealed the composers' real intention in their music. For example, Huang Anlun's Overture and Dance suite for piano solo was originally titled China Rhapsody No. 2: People of Mesa Ethnicity Asking for Liberation. However, due to the political coercion, and criticism made by Yu Huiyong (于会勇) and Yin Chengzong, Huang adapted the national anthem East is Red and orchestrated

Guang Lu, "Modern Revolutionary Beijing Opera: Context, Contents and Conflicts,"(PhD diss., Kent State University, 1997).

21 Robert Chi, "The March of the Volunteers: From Movie Theme Song to National Anthem," in Re-envisioning the Chinese Revolution: The Politics and Poetics of Collective Memories in Reform China, eds. Ching Kwan Lee and Guobin Yang (Washington, D.C.: Woodrow Wilson Center Press, 2007), 217-244; Marc L. Moskowitz, Cries of Joy, Songs of Sorrow: Chinese Pop Music and Its Cultural Connotations (Honolulu: University of Hawai'i Press, 2010).

22 Xing Lu, Rhetoric of the Chinese Cultural Revolution: The Impact on Chinese Thought, Culture, and Communication (Columbia, SC: University of South Carolina Press, 2004).

23 Ibid., 104.

24 Chun Ya Chang, "The Yellow River Piano Concerto: A Pioneer of Western Classical Music in Modern China and Its Socio-Political Context" (DMA diss., University of Alabama, 2017); Sheila Melvin and Jindong Cai, Rhapsody in Red: How Western Classical Music Became Chinese (New York: Algora Publishing, 2004); Laikwan Pang, Paul Clark, and Tsan Huang Tsai, Listening to China's Cultural Revolution: Music, Politics, and Cultural Continuities (Hampshire: Palgrave MacMillan, 2016).

25 Maochun Liang, "Wenhua Dageming Shiqi de Yinyue - We Wenge Jieshu Ershinian er Zuo," ["The Music in Cultural Revolution - For the Twenty-Year Temination of Cultural Revolution"], Jiao Xiang-Journal of Xi'an Conservatory of Music, no. 4 (1996): 17-21. 
the piece as a symphonic work, and abandoned the Mesa ethnic music elements. ${ }^{26}$ In China, tolerance to creativity liberalism increased only after the incident on September 13, 1971 (the Lin Biao incident), after which Zhou Enlai (周恩来) and Deng Xiaoping (邓小平) presided the work of the Political Bureau and restored the social order in the country. ${ }^{27}$ The period was followed by a proliferation of "new wave" music.

Zhao Xiaosheng (b. 1945) is one of the representative figures of the "new wave" composers, and one of his most notable contributions is the Tai Chi composition system. ${ }^{28}$ Zhao was born in a musical family and began his music lessons at the age of six. His father was a violinist at the Shanghai Municipal Orchestra and a professor at the Shanghai Conservatory of Music. After graduating from the Shanghai Conservatory of Music with a bachelor's degree, Zhao was forced to participate in the rustication program as a fisherman under the Laogai system in 1975. His experience in fishing led to the composition of his piano solo Yuge (渔歌, Fisherman Song). ${ }^{29}$ Zhao recalled his hardship as a fisherman on a fishing vessel of just 37 tonnage that sailed often through rough sea with waves twice as higher as the room in his house, and he stated that he faced nausea and vomiting every day during this period. ${ }^{30}$

An influence from the Laogai experience may seem evanescent, but it was the purge of the intellectuals and the denouncement of his father during the early period of the Cultural Revolution that was inconceivable to Zhao. The traumatic aftermath of his father's death led to the creation of his two piano solos: Ballade in Db Major (published in 1977) and Ballade in D Gong Scale (1976). These two pieces are the only ballades written by Zhao. Although Zhao initially planned on writing four ballades like Chopin, he stopped writing the ballades after Ballade in Db Major. Two hidden facts were brought to our attention during the study of these two ballades. Firstly, the actual year of commencement and completion of Ballade in Db Major is 1976, and the completion date of this work was fabricated as the musical elements in this work were deemed illegitimate during the harsh time of the Cultural Revolution. This hidden truth was revealed by the composer only in 2016. Therefore, both ballades were never listed under the composer's official biography and the

26 Bin Zhang, "Huang Anlun Xuqu yu Wuqu de Chuangzuo Jingguo yu Mingming Qianhou," ["The Compositional Procedure and Title Source of Huang Anlun's Overture and Dance"], Journal of Tianjin Conservatory of Music (Sounds of Nature), no. 3 (2016): 34-35.

27 Guo Jian, Yongyi Song, and Zhou Yuan, Historical Dictionary of the Chinese Cultural Revolution (Maryland, Toronto and Oxford: The Scarecrow Press, 2006), 251.

28 Ke Xue and Fung Ying Loo, "Transcoding the I Ching as Composition Tecniques in Chou Wen Chung, Zhao Xiaosheng and Chung Yiu Kwong," Revista Música Hodie 19 (2019): 1-29, https:// doi.org/10.5216/mh.v19.52739.

29 See Ke Xue and Fung Ying Loo, "Reminiscing Crashing Waves and Romanticism in Zhao Xiaosheng's Fisherman Song," Malaysian Journal of Performing and Visual Arts, no. 3 (2017): 8.

30 Xiaosheng Zhao, interview, November 4, 2016, Shanghai, China. 
scores were published in Zhao Xiao Sheng Solo Piano Works (赵晓生钢琴独奏 作品集) much later by Shanghai Music Publishing House in 2015. Secondly, there were obvious Western elements in this work that were perceived with a derogatory "bourgeoisie" label by the Red Guards during the revolution. Such "Western" elements were also found in our analysis of the "legitimate" Ballade in D Gong Scale written in the same year. Therefore, we revisited the two ballades and their political sentiment, and examined them as cultural artefacts of the bitter incident of China's Cultural Revolution. This paper unveils the reason behind the fabricated date of the completion of Ballade in Db Major, the composer's difficulty to differentiate between his emotions of fear and anger, and suppressed hostility, and the much-politicized musical compositions.

\section{Reflecting fear and anger: The ballades of suppressed hostility}

A hidden element of emotional turmoil is embedded in the two ballades of Zhao Xiaosheng. After his father, along with ten other professors who were purged during the Cultural Revolution, fear might have been the core factor in Zhao's emotional turmoil when he composed the two ballades in 1976. Zhao's piano solo Ballade in Db Major was an emotional response of anguish and anger to the purge. Feeling powerless against the Red Guards, Zhao created a secretive rebellious pastiche of Western art music during the Cultural Revolution. However, the actual date of writing and completion of the ballade was masked out of fear. The composer gives the following explanation for the fabrication:

I concealed the completion date of this work. The actual completion date is much earlier than what was mentioned at the time of the publication. But I did not point it [the actual completion date] out, because I was afraid that people would associate this piece with political events. ${ }^{31}$

The purge of musicians resulted in Zhao's antagonistic attitude towards the Communist Party. Thus, when Western art music works were prohibited by the Communist Party, the composer continued to embrace them in the Ballade in Db Major. However, the fear of death kept the composer from any further act of hostility, as he explained below:

Do you know why I did not publish this piece [at that time]? Because I could not publish this work during the Cultural Revolution. If I had published this work, I would have had been killed. You can easily distinguish that it [Ballade in Db Major] fights against the Cultural Revolution. This is a sound from my heart. I am different from Yin Chengzong. Yin advocated the Cultural Revolution. Thus, I could not publish my work. I put it in my drawer after it was completed. ${ }^{32}$

31 Ibid; translation by authors.

32 Ibid; translation by authors. 
On the other hand, Zhao's rebellion and fear regarding the political situation of the period of the Cultural Revolution polarized into the Ballade in D Gong Scale, where the work seemingly conforms to the political propaganda. Zhao expressed his sarcasm and anger towards the Red Guards in the following statement:

The Ballade in $\mathrm{Db}$ Major is a Westernized work. It's fashionable. After composing the Ballade in Db Major, I intentionally created the Ballade in D Gong Scale, a completely Chinese style work. [It was] my purpose. You say I am Westernized? Ok. I have written a very Chinese work that is an opposite to my former work. You cannot describe my work as Westernized; my work is Sinicized. ${ }^{33}$

The pronoun "you" in the above statement refers to the Red Guards, and Zhao condemned their rash, illegal, and cruel behaviors with respect to the death of the musicians. For Zhao, his two works were an emotional outpour to express his anguish, and his sarcasm towards the faction. Zhao explained that the Ballade in D Gong Scale was composed as a complementary piece to the Ballade in Db Major. The former work does not conform to the rules approved by the Union of Chinese Musicians, as Zhao explained in the following statement:

There are some factions in the Red Guards, such as the rebel faction and conservative faction. I don't have any quality that makes me suitable to be a member of the Red Guards. People can join the Red Guards only if they belong to the five red categories. I belong to the five black categories... It is impossible to praise the Red Guards. We stand on opposite positions. ${ }^{34}$

Zhao's hatred and fear of the Cultural Revolution led to the input of sarcasm and rebellious illegitimate musical elements into the Ballade in Db Major. This was unknown to the Red Guards, and this phenomenon was perhaps similar to Beyer's discussion on aggression, rebellion, and deprivation as a result of stress. ${ }^{35}$ On the other hand, the piece Ballade in D Gong Scale reveals Zhao's sarcasm toward the politics of Mao, Red Guards, and also toward the aesthetics of that time. Both of Zhao's works displayed an underlying tone of "rebellion," with an emotional entanglement of anguish, fear, and antagonism.

33 Ibid; translation by authors.

34 Ibid, translation by authors. During the Cultural Revolution, two classes were defined as the five red categories and five black categories. The five red categories consisted of "revolutionary cadres, revolutionary martyrs, revolutionary soldiers, workers, and poor and lower-middle class peasants," and the five black categories consisted of "landlords, rich peasants, counterrevolutionaries, criminals, and rightists."Xing Lu, Rhetoric of the Chinese Cultural Revolution: The Impact on Chinese Thought, Culture, and Communication (South Carolina: University of South Carolina, 2004), 55.

35 Anna Cornelia Beyer, International Political Psychology: Explorations into a New Discipline (London: Macmillan Publishers Ltd, 2017), 32. 
Thus, the following sections regarding the musical analysis of Zhao's ballades reveal Zhao's experience and intention in his compositions during the late Cultural Revolution period, and consider his two ballades as a form of rightist sentiment.

\section{Ternary form: Chinese and Western aesthetics}

A similar musical form is employed in both Ballade in Db Major and Ballade in D Gong Scale. Both works display a compound structure with a 16-bar introduction and a coda (Table 1a and Table 1b).

Table 1a: The structure of Ballade in Db Major

\begin{tabular}{|l|c|c|c|c|c|c|c|c|c|c|}
\hline Parts & Intro. & \multicolumn{2}{|c|}{$\mathrm{A}$} & \multicolumn{5}{|c|}{$\mathrm{B}$} & $\mathrm{A}^{1}$ & Coda \\
\hline Sections & & $\mathrm{A}$ & $\mathrm{B}$ & Trans. & $\mathrm{C}$ & $\mathrm{C}^{1}$ & $\mathrm{C}^{2}$ & Comple. & $\mathrm{B}^{1}$ & \\
\hline Measures & $1-16$ & $17-44$ & $45-79$ & $80-85$ & $\begin{array}{c}86- \\
105\end{array}$ & $\begin{array}{c}106- \\
134\end{array}$ & $\begin{array}{c}135- \\
152\end{array}$ & $153-163$ & $\begin{array}{c}164- \\
188\end{array}$ & $\begin{array}{c}189- \\
193\end{array}$ \\
\hline
\end{tabular}

Table 1b: The structure of Ballade in D Gong Scale

\begin{tabular}{|l|c|c|c|c|c|c|c|c|c|c|c|c|c|}
\hline Parts & Intro. & \multicolumn{4}{|c|}{$\mathrm{A}$} & \multicolumn{3}{|c|}{$\mathrm{B}$ (Trio) } & \multicolumn{4}{|c|}{$\mathrm{A}^{1}$} & \multicolumn{2}{c|}{ Coda } \\
\hline Sections & & $\mathrm{A}$ & $\mathrm{B}$ & $\mathrm{A}^{1}$ & $\mathrm{C}$ & $\mathrm{D}$ & $\mathrm{C}^{1}$ & Intro. & $\mathrm{A}$ & $\mathrm{B}$ & $\mathrm{A}^{2}$ & $\mathrm{D}^{1}$ & $\mathrm{~A}^{3}$ \\
\hline \multirow{2}{*}{ Measures } & \multirow{2}{*}{$1-16$} & $17-$ & $33-$ & $82-$ & $116-$ & $132-$ & $149-$ & $171-$ & $185-$ & $201-$ & $250-$ & $257-$ & $274-$ \\
& & 32 & 81 & 115 & 131 & 148 & 170 & 184 & 200 & 249 & 256 & 273 & 288 \\
\hline
\end{tabular}

The analysis of the internal structures of the two ballades resulted in discovery of embedded elements that reflect Zhao's emotional turmoil during the composition of the ballades. The middle section of both ballades shows different attributes. The Ballade in Db Major has a variation structure of Chinese aesthetic while the Ballade in D Gong Scale utilizes a trio with a Western flavor. The variation form, one of the most common structures in traditional Chinese music, ${ }^{36}$ is different than the Western variation form in terms of its length. The former merely occupies one part or section in a work while the latter denotes a whole piece or movement commonly found in Western art music by composers such as Bach, Beethoven, Mozart, and Brahms. Zhao utilizes a dual-theme variation in Ballade in Db Major to describe the emotions of infighting and collision (Examples 1a, 1b, 1c, and 1d).

36 Jiti Li, Zhongguo Yinyuejiegou Fenxi Gailun [General Analysis of Chinese Music Structure] (Beijing: Central Conservatory of Music Press, 2004), 198-220. 

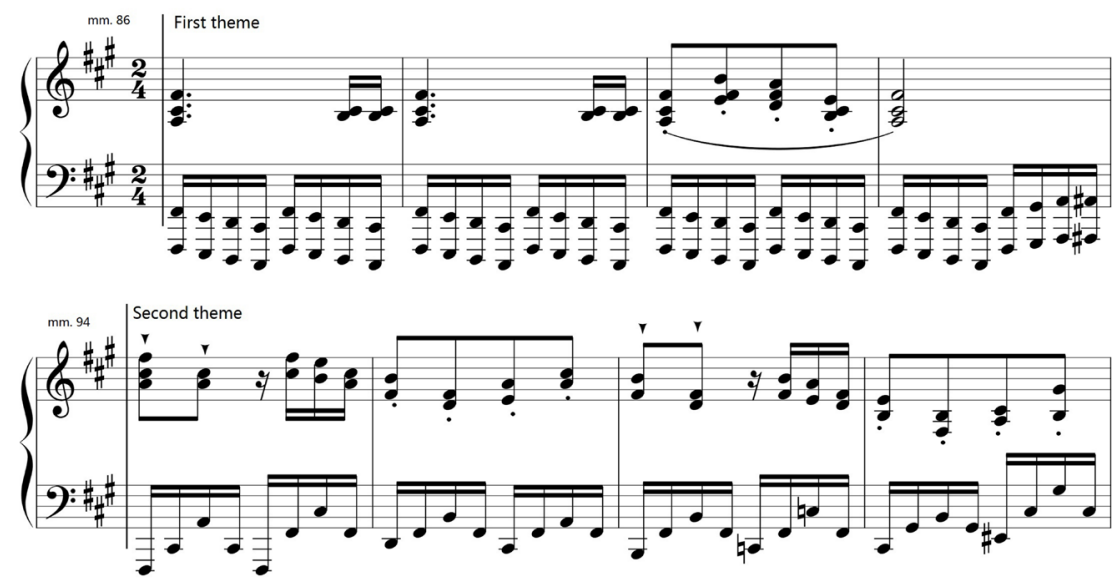

Example 1a: The partial dual theme in Ballade in Db Major, mm. 86-89 and 94-97.
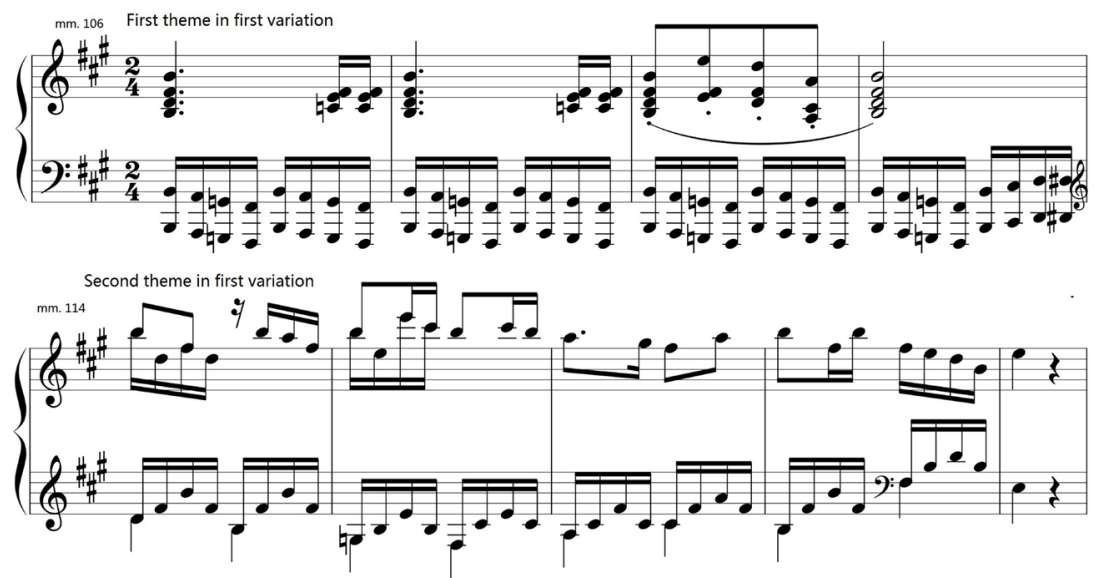

Example 1b: The partial first variation, mm. 106-109 and 114-118.

Compared to the complex structure of Ballade in Db Major, the trio in Ballade in D Gong Scale appears simpler as it uses ordinary ternary form to establish its middle section. Zhao also borrows the concept of $q i$, cheng, zhuan, and he from Chinese classic literature and uses it in the section A of Ballade in D Gong Scale. Qi, cheng, zhuan and he is a text structure employed in traditional Chinese literature. A scholar of the Qing Dynasty Liu Xizai (刘熙载) explained the form as:

起、承、转、合四字, 起者, 起下也, 连合亦起在内; 合者, 合上也, 连起 也合在内, 中间用承用转, 皆兼顾起合也。 

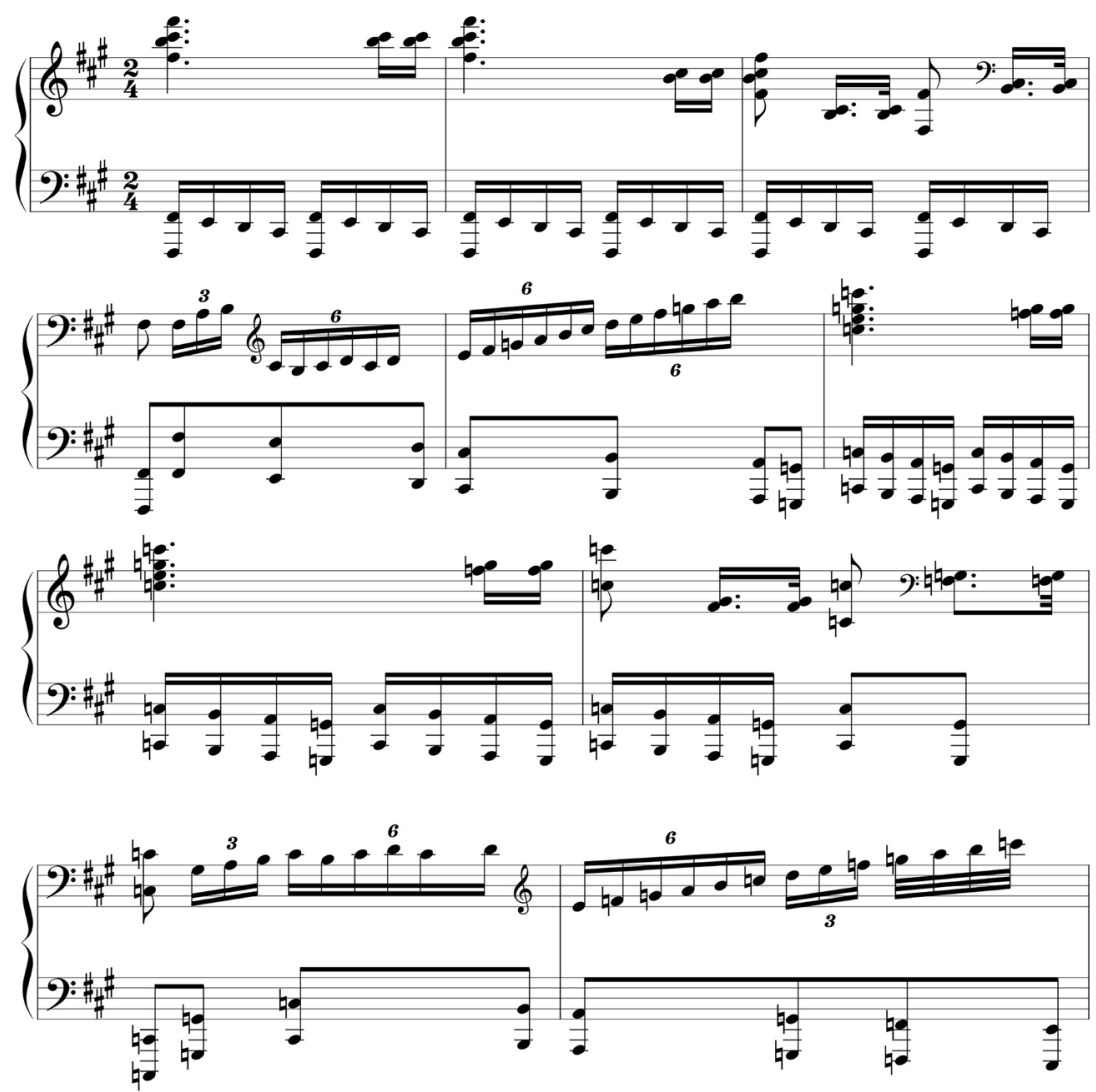

Example 1c: The first theme in the second variation, mm. 135-144.

Qi, cheng, zhuan, and he: within qi [opening], there is he [summary], and he is a response to the beginning of the text. Within he, there is again qi, and the coherence of cheng [continuation] and zhuan [transition] form the structure of the text. In this way, a complete text is presented. ${ }^{37}$

The form of qi, cheng, zhuan, and he is also studied in Chinese metaphysics, Chinese thought and conventional psychology. ${ }^{38}$ The four-phrase concept of $q i$, cheng, zhuan, and he is one of the most common structures in traditional Chinese music. This is due to the similarity of syntax and logic of this structure

37 Xizai Liu, Yigai (Jingyi Gai) [Generality of Arts (Generality of Jingyi)] (Shanghai: Shanghai Ancient Books Publishing House, 1978), 177; translation by authors.

38 Qiang Huang, "Lun Qichengzhuanhe," ["Discussion of qi, cheng, zhuan and he"], Jinyang Xuekan, no. 3 (2010): 124-129. 

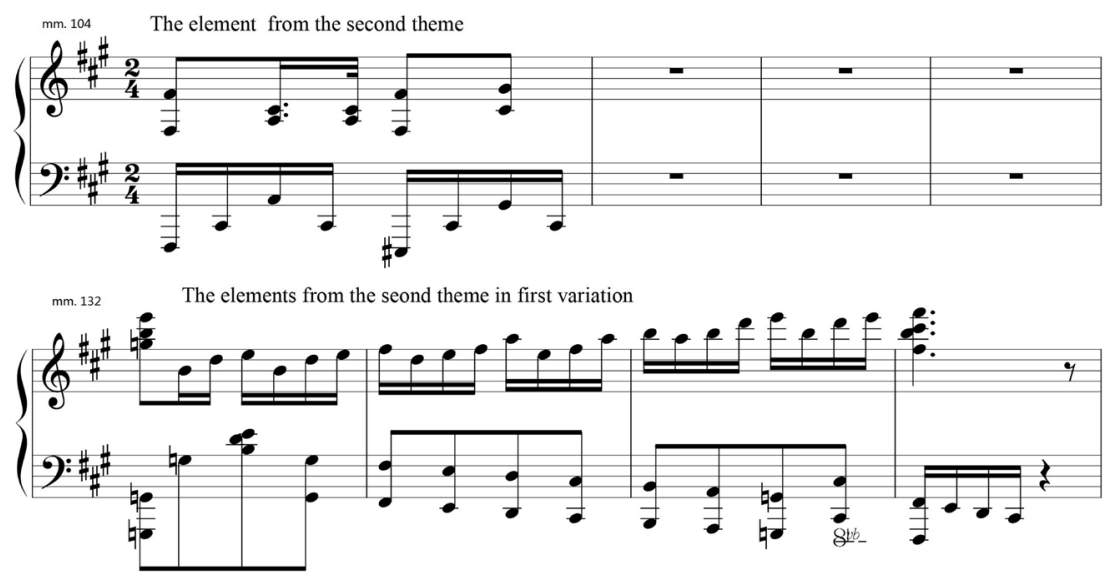

mm. 145 The first half of the seond theme in second variation
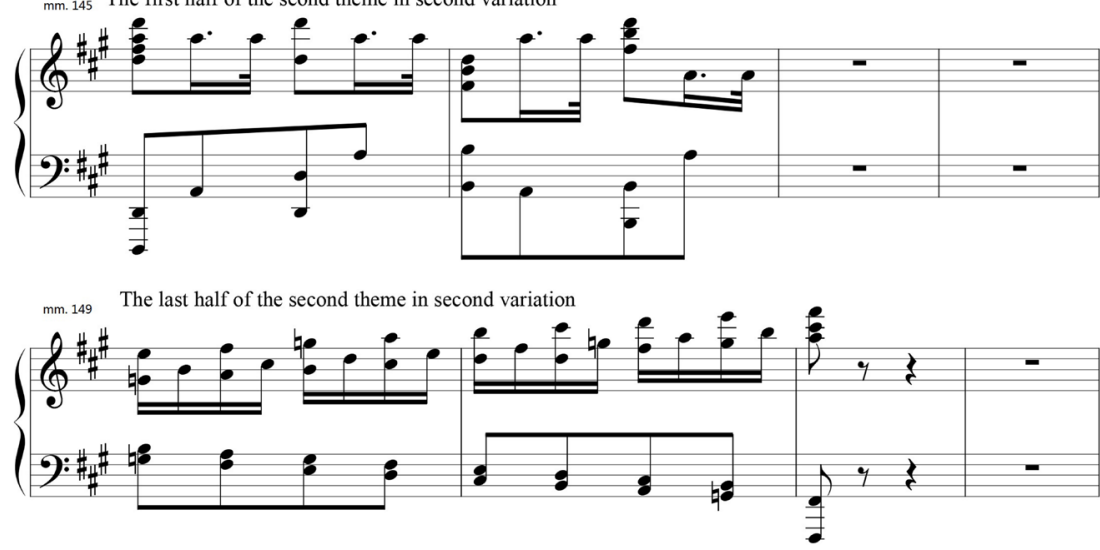

Example 1d: The constitution of the second theme in the second variation, mm. 104, 132-134, 145-146, and 149-151.

to that of the ancient poems, ${ }^{39}$ and its common use in music composition led to the pertinent works being described as having a more "Chinese" identity. ${ }^{40}$

In Ballade in D Gong Scale, the form of qi, cheng, zhuan and he frames the melody of the theme in section A (Example 2), where the first and second phrases are $q i$ and cheng respectively, along with the same first two-bar elements and slightly different last two-bar elements. The third phrase, as the role of zhuan, is transformed greatly, ranging from pitches to rhythmic patterns.

39 Jiti Li, Zhongguo Yinyuejiegou Fenxi Gailun [General Analysis of Chinese Music Structure] (Beijing: Central Conservatory of Music Press, 2004), 164.

40 Le Kang, “The Development of Chinese Piano Music," Asian Culture and History 1, no. 2 (2009): $18-33$. 
Performing the function of closure, the first phrase, he, strengthens the tonic function in a tonality.

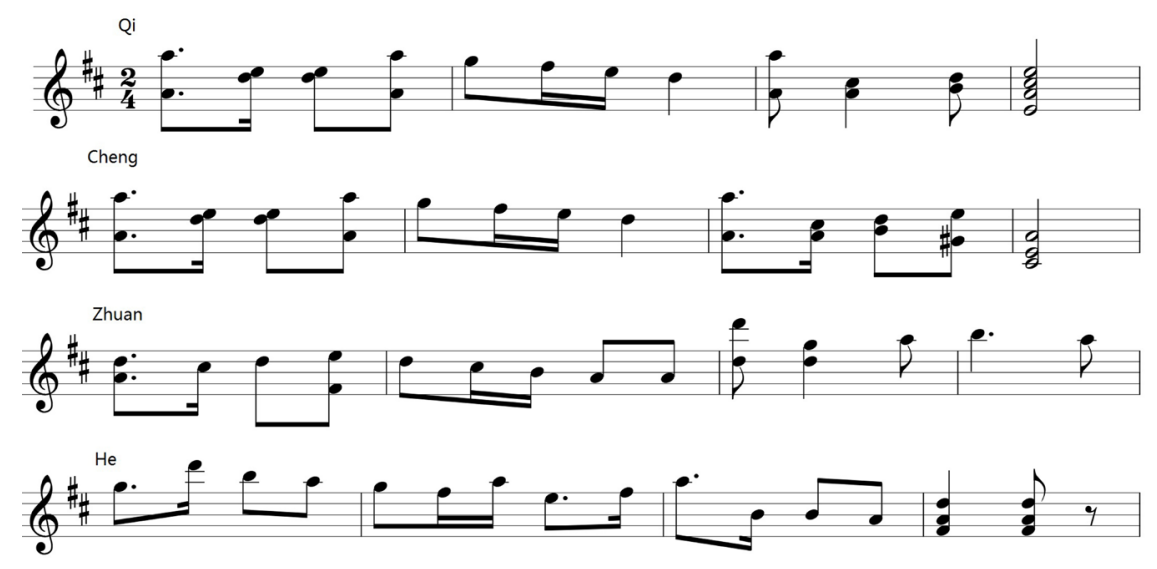

Example 2: The form of qi, cheng, zhuan and he in Ballade in D Gong Scale, mm. 17-32.

Zhao's original intention in both ballades is shown through a complex and fabricated employment of Western and Sinicized style in order to express his sarcasm and rebellion towards the Cultural Revolution. However, after analyzing the two pieces, we found that the Chinese elements employed in Ballade in Db Major which is a pastiche of Western art music, and the Western elements used in the Ballade in D Gong Scale, contradict Zhao's statements. Perhaps, this contradiction reflects Zhao's emotional confusion comprising emotions such as anxiety, anger, hostility, indecisive allegiance towards the faction, along with the repression of his musical aesthetical background due to severe political torment.

\section{Tempo fluctuation and rhythmic characteristics}

The use of tempo fluctuation in both Ballade in Db Major and Ballade in D Gong Scale was analyzed and illustrated in Figure 1 and Figure 2. In reference to the previous examples, the two ballades have a symmetrical temporal morphology and both works have opposite forms of tempo progression: 1) slow $\rightarrow$ fast $\rightarrow$ slow in Ballade in Db Major, and, 2) fast $\rightarrow$ slow $\rightarrow$ fast in Ballade in $D$ Gong Scale. In addition, the fastest speed marked on Ballade in Db Major is merely $d=100$, which is close to the slowest speed in Ballade in D Gong Scale. Zhao explained that the introduction of Ballade in Db Major in Largo and marked quasi senza misura depicts a tense atmosphere. ${ }^{41}$

41 Xiaosheng Zhao, interview, November 4, 2016, Shanghai, China. 


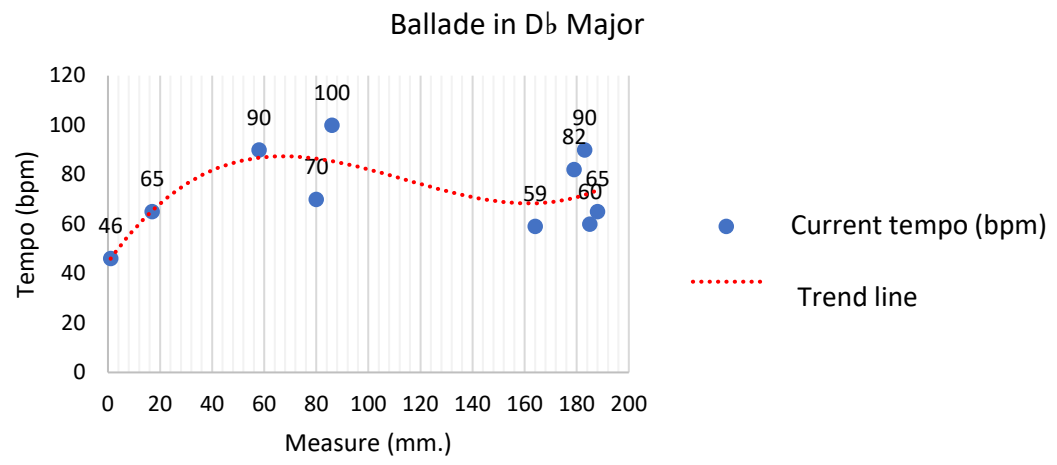

Figure 1: The tempo fluctuation of Ballade in Db Major.

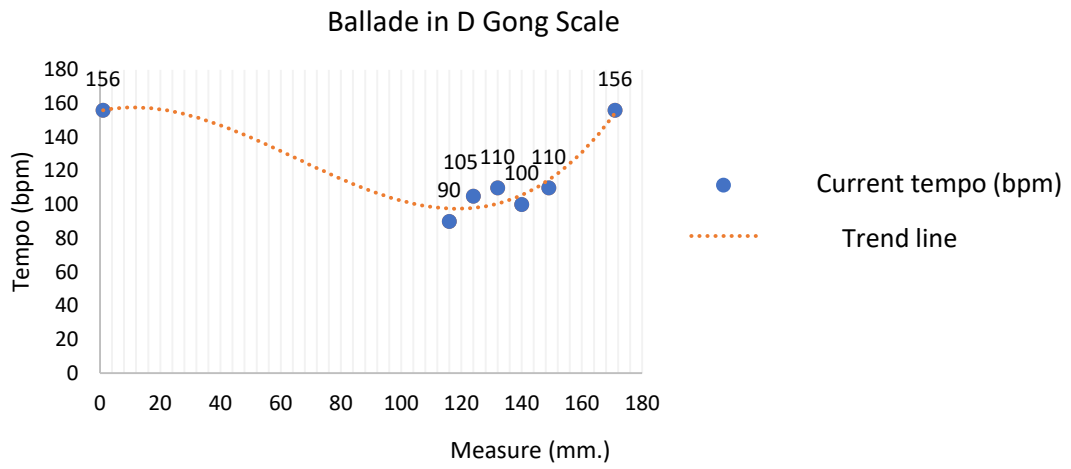

Figure 2: The tempo fluctuation of Ballade in D Gong Scale.

The composer's performance recorded during his recital at Beijing on October 4, 2016 revealed that the section was played at $d=46$. The section symbolized the obsequies of musicians purged during the Cultural Revolution. This passage was performed at $d=65$, and the music under the tempo of $d=90$ displayed an imaginary escapism from the brutal reality of the revolution. In contrast, Zhao confessed during the interview that the speed marked at $d=156$ in the section of Ballade in D Gong Scale (wherein the section is dominated by percussive imitation) reflects a somewhat pseudobulbar laugh of sarcasm towards the Red Guards. Thus, the tempi probably portray the emotional chaos where the former $(d=65)$ represents grief and the latter $(d=90)$ represents gaiety.

Apart from tempo fluctuation, Zhao applies distinct rhythmic patterns to present different emotions in the two ballades. For example, Zhao borrowed the same speed of Chopin's Funeral March $(d=65)$ to depict the scene of the 
purged musicians' obsequies in Ballade in Db Major (see Example 7, see later "harmony"). This work also borrowed a rhythmic pattern from Chopin's Polonaise in Ab major, Op. 53, which comprises an ostinato of octaves along with sixteenth-note quadruplets (Example 3), and this borrowed element portrayed the composer's inner struggle, distress, and uneasiness during the period of Cultural Revolutionary. ${ }^{42}$

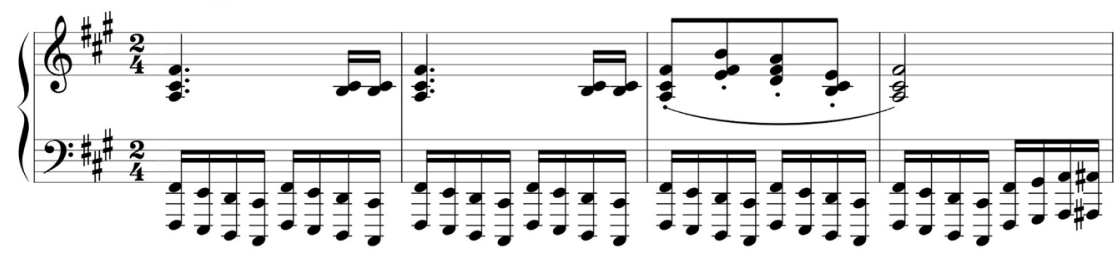

Example 3: The rhythmic pattern from Chopin' Polonaise in Ballade in Db Major, mm. 86-89.

In the piece Ballade in D Gong Scale, Zhao employed a particular rhythmic pattern to imitate the soundscape of gongs and drums (Example 4), the instruments essential to traditional Chinese music. This rhythmic pattern consists of two portions that are distributed in the right and left hands. On the right hand, a dotted eighth note with a sixteenth note and three groups of eighth notes in a duplet establish a rhythmic mode. On the left hand, two dotted-fourth notes along with a fourth note shape the basic beats. The accents marked on the score represent a typical Chinese aesthetic rhythmic pattern: "1-4-7", which Zhao emphasized and marked with accents. ${ }^{43}$ In addition, this rhythmic pattern surpasses the limitation of a bar line, and the two-bar music here is viewed as an entirety.

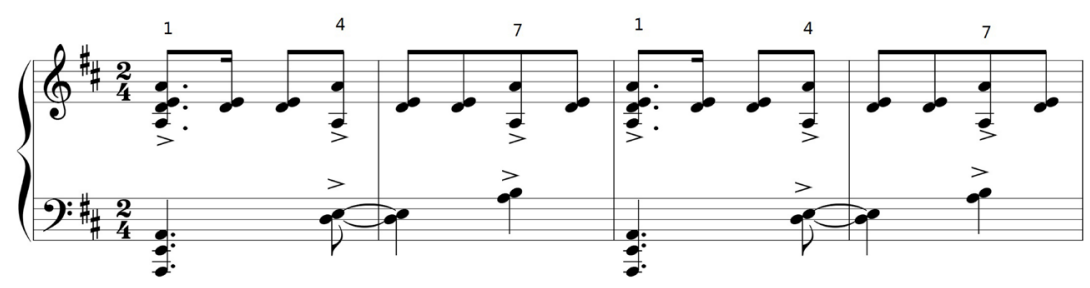

Example 4: The rhythmic pattern of "1-4-7" in Ballade in D Gong Scale, mm. 1-4.

42 Ibid.

43 Ibid. 


\section{Chinese and Western theories regarding tonality and harmony}

In past literatures regarding Chinese new music, a popular debate regarding Chinese elements and the notion of Chinese identity particularly focuses on the music composed during the Cultural Revolution. ${ }^{44}$ The compositions of that period were of a nationalistic nature and they were perceived as a political byproduct to a certain extent. ${ }^{45}$ The music of this period popularly used traditional Chinese modes such as pentatonic, hexatonic, and heptatonic scales. During the three-decade blockade from the West and the one-sided diplomatic policy of the new Chinese government during the years 1949-1977,46 the composers' cognition of Western music was largely limited to the music of the Classical and Romantic period that they were exposed to before the restriction imposed on the arts during the Cultural Revolution. ${ }^{47}$ Therefore, Western music was given the label of "pentatonic romanticism" by the Chinese musicians. ${ }^{48}$ The same factor applies to Zhao's Ballade in D Gong Scale that employs Chinese pentatonic scale as its mode (Table 2).

Table 2: The tonal structure of Ballade in D Gong Scale

\begin{tabular}{|c|c|c|c|c|c|c|c|c|c|c|c|c|c|}
\hline Part & Intro. & \multicolumn{3}{|c|}{$\mathrm{A}$} & \multicolumn{3}{|c|}{\begin{tabular}{|l|}
$\mathrm{B}$ \\
(Trio)
\end{tabular}} & \multicolumn{4}{|c|}{$\mathrm{A}^{1}$} & \multicolumn{2}{|c|}{ Coda } \\
\hline Section & & A & B & $\mathrm{A}^{1}$ & $\mathrm{C}$ & D & $\mathrm{C}^{1}$ & Intro. & A & B & $A^{2}$ & $\mathrm{D}^{1}$ & $\mathrm{~A}^{3}$ \\
\hline Measures & $1-16$ & $\begin{array}{c}17- \\
32\end{array}$ & $\begin{array}{c}33- \\
81\end{array}$ & $\begin{array}{l}82- \\
115\end{array}$ & $\begin{array}{l}116- \\
131\end{array}$ & $\begin{array}{c}132- \\
148\end{array}$ & $\begin{array}{c}149- \\
170\end{array}$ & $\begin{array}{c}171- \\
184\end{array}$ & $\begin{array}{c}185- \\
200\end{array}$ & $\begin{array}{c}201- \\
249\end{array}$ & $\begin{array}{r}250- \\
256\end{array}$ & $\begin{array}{c}257- \\
273\end{array}$ & $\begin{array}{r}274- \\
288\end{array}$ \\
\hline Key & $\begin{array}{c}\mathrm{D} \\
Z h i \\
\text { scale }\end{array}$ & $\begin{array}{r}\mathrm{D} Z h . \\
G\end{array}$ & $\begin{array}{l}\text { iscal } \\
n g \text { sc }\end{array}$ & $\rightarrow$ D & $\begin{array}{c}\text { G } \\
\text { Gong } \\
\text { scale }\end{array}$ & $\begin{array}{c}\mathrm{D} \\
Z h i \\
\text { scale }\end{array}$ & $\begin{array}{c}\text { C } \\
\text { Gong } \\
\text { scale }\end{array}$ & $\begin{array}{c}\mathrm{D} \\
Z h i \\
\text { scale }\end{array}$ & $\mathrm{D} Z$ & bi scal & $\rightarrow D$ & Gong & scale \\
\hline $\begin{array}{l}\text { Gong } \\
\text { system }\end{array}$ & & I & & & & $G$ & $\mathrm{C}$ & & & & & & \\
\hline
\end{tabular}

44 Zhenya Wang, Zhongguo Zuoqu Jifa de Yanbian [The Development of Chinese Compositional Techniques] (Beijing: Central Conservatory of Music Press, 2004), 235; Frederick Lau, "Voice, Culture, and Ethnicity in Contemporary Chinese Compositions," in Vocal Music and Contemporary Identities: Unlimited Voices in East Asia and the West, eds. Christian Utz and Frederick Lau (New York: Routledge, 2013), 99-115.

45 Barbara Mittler, "Chinese New Music as a Politicized Language: Orthodox Melodies and Dangerous Tunes," in Language and Politics in Modern China, eds. Jeffery Wasserstrom and Sue Tuohy (Bloomington, Indiana: Indiana University, 1996), 1-22.

46 Paul D'Anieri, International Politics: Power and Purpose in Global Affairs (Boston: Cengage Learning, 2011).

47 Nancy Yunwha Rao, "Hearing Pentatonicism Through Serialism: Integrating Different Traditions in Chinese Contemporary Music," Perspectives of New Music 40, no. 2 (2002): 191.

48 Barbara Mittler, Dangerous Tunes: The Politics of Chinese Music in Hong Kong, Taiwan, and the People's Republic of China since 1949 (Wiesbaden: Harrassowitz, 1997), 133. During the revolutionary period, musicians were restricted to musical influence from the Soviet Union. Anguo Wang, "Xinchao Yinyue," ["New Wave Music"], 64; Zhenya Wang, Zhongguo Zuoqu Jifa de Yanbian [The Development of Chinese Compositional Techniques], 235. 
In Ballade in D Gong Scale, either the tonggong fandiao (同宫犯调, modulations in the same Gong mode) that occurs in sections $\mathrm{A}$ and $\mathrm{A}^{1}$, or the yigong fandiao (异宫犯调, modulations in different Gong mode) employed in the three sections reveal a development within the pentatonic scale, even though they are transformed into a hexatonic scale and heptatonic scale through the addition of the bianyin (变音). ${ }^{49}$ Example 5 shows a hexatonic scale with bianzhi $\mathrm{D}$ while Example 6 is an example of a heptatonic scale with qingjue and biangong.

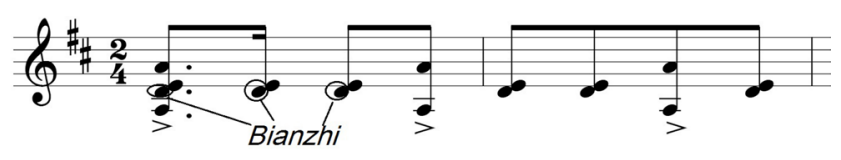

Example 5: Hexatonic scale in Ballade in D Gong Scale, mm. 1-2.

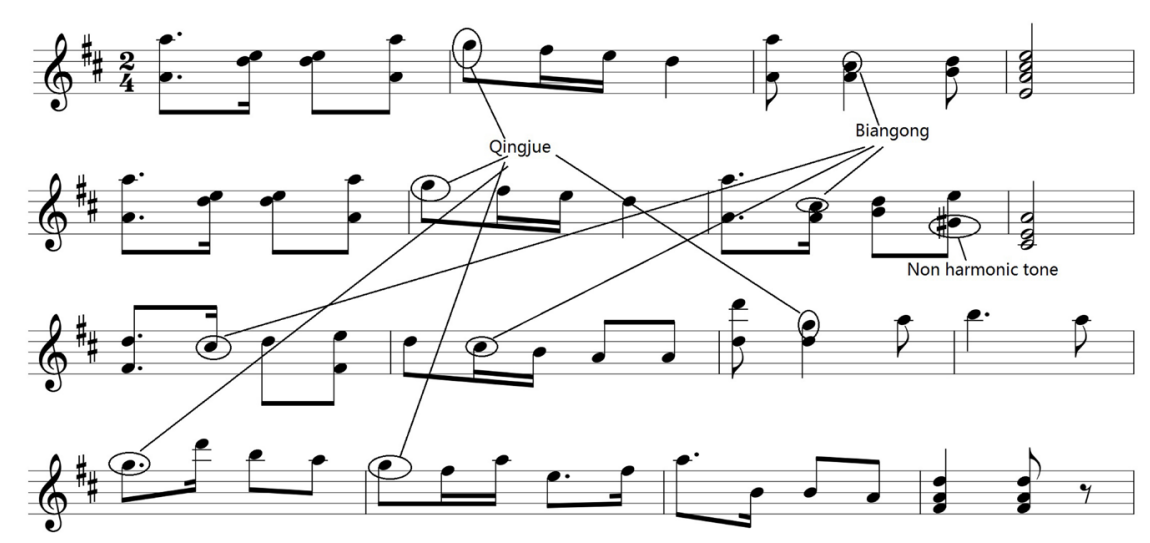

Example 6: Heptatonic scale in Ballade in D Gong Scale, mm. 17-32.

It is found that the tonality and harmony of Ballade in D Gong Scale employs the Western major and minor key, concurring to Zhao's statement that the Ballade in Db Major was Westernized and that the Ballade in D Gong Scale was composed with a nationalistic theme. ${ }^{50}$ The details of this finding are shown in Table 3.

49 Bianyin are the additional notes of the pentatonic scale, which include biangong (变宫, B note), qingjue (清角, F note), bianzhi (变徵, F\# note), and run (闰, Bb note).

50 Xiaosheng Zhao, interview, November 4, 2016, Shanghai, China. 
Table 3: The tonal structure of Ballade in Db Major

\begin{tabular}{|l|c|c|c|c|c|c|c|c|c|c|}
\hline Parts & Intro. & \multicolumn{2}{|c|}{$\mathrm{A}$} & \multicolumn{5}{|c|}{$\mathrm{B}$} & $\mathrm{A}^{1}$ & Coda \\
\hline Sections & & $\mathrm{A}$ & $\mathrm{B}$ & Trans. & $\mathrm{C}$ & $\mathrm{C}^{1}$ & $\mathrm{C}^{2}$ & Comple. & $\mathrm{B}^{1}$ & \\
\hline Bars & $1-16$ & $17-44$ & $45-79$ & $80-85$ & $\begin{array}{c}86- \\
105\end{array}$ & $\begin{array}{c}106- \\
134\end{array}$ & $140-153$ & $154-163$ & $\begin{array}{c}164- \\
188\end{array}$ & $\begin{array}{c}189- \\
193\end{array}$ \\
\hline Key & $\begin{array}{c}\mathrm{Db} \\
\text { major }\end{array}$ & $\begin{array}{c}\mathrm{Bb} \\
\text { minor }\end{array}$ & $\begin{array}{c}\mathrm{Db} \\
\text { major } \\
\text { to Gb } \\
\text { major }\end{array}$ & F\# minor & $\begin{array}{c}\text { Bb } \\
\text { minor }\end{array}$ & $\begin{array}{c}\text { Bb minor, } \\
\text { C major, } \\
\text { and D } \\
\text { major }\end{array}$ & D major & Db major \\
\hline
\end{tabular}

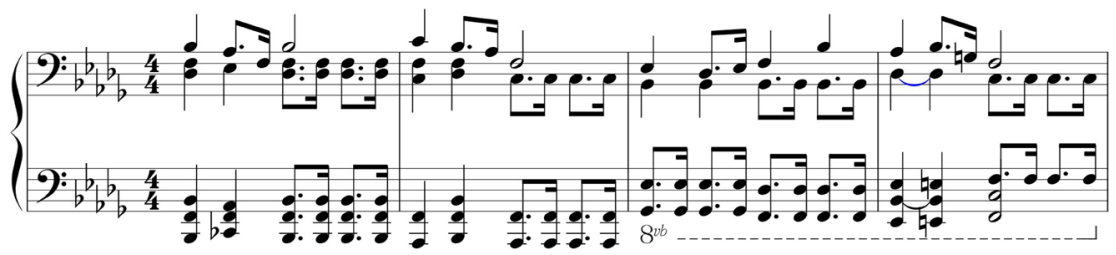

Example 7: The imitation of Chopin's Funeral March, mm. 17-20.
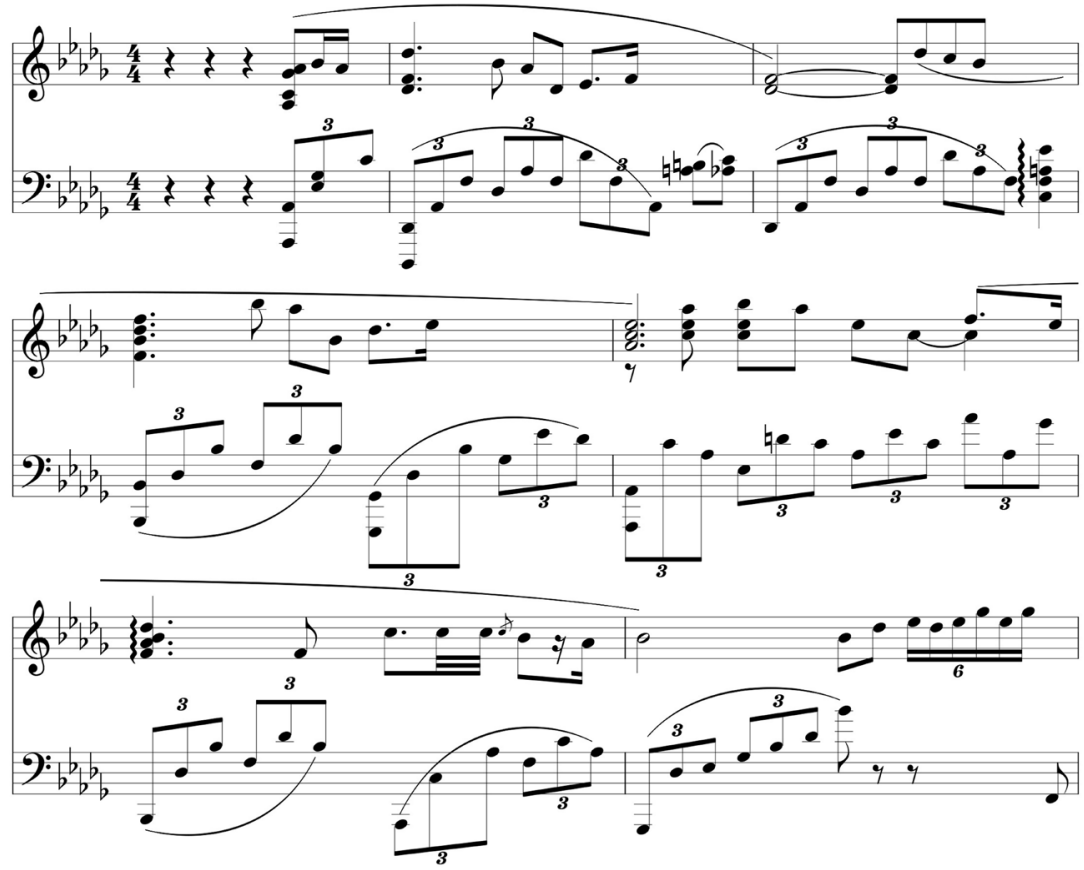

Example 8: The imitation of Liszt's Liebestraum, No. 3, mm. 44-50. 
Furthermore, even though the use of $\mathrm{Bb}$ minor in section $\mathrm{A}$ breaks away from the conventional rule of the Classical and Romantic period music wherein the tonic key appears in the first section, Zhao's direct borrowing of Chopin's Funeral March (third movement of Piano Sonata No. 2, Op. 35) makes the section A's tonality and rhythmic pattern is obvious (Example 7). The influence of Western art music on Ballade in Db Major is also clearly seen when a harmonic writing that mimicked Liszt's Liebestraum No. 3 is detected in section B (Example 8).

During an interview, Zhao stated that he created his pastiche of Western art music to express sarcasm towards the Cultural Revolution:

\begin{abstract}
In the piece Ballade in Db Major, you can hear the sounds from Chopin, Liszt, and Scriabin. These sounds speak my mind, because they record my spiritual feelings during the Cultural Revolution. I composed a section [in Ballade in Db Major] that is identical to a section in Chopin's Funeral March. Everything is the same between these two sections, including the tonality, harmony, and rhythm. I used it [section from Chopin's Funeral March] intentionally. Do you know why I did this? My father was killed in the early days of the Cultural Revolution. 11 professors of the Conservatory of Music were killed at that time. I "buried" these musicians in this piano work, since I could not express my grief openly... You can also imagine why I hid the date of completion of these works. The real date of the completion of these works is earlier than what was marked on the publications. I didn't tell the truth during that time, because I did not want people to associate the Ballade in $\mathrm{Db}$ Major with this event [the purging of the musicians]. ${ }^{51}$
\end{abstract}

An embedded antagonistic desire in Zhao resulted in his persistence to compose a pastiche of Western art music. However, perhaps out of fear, fabricating the completion date of work marked a reservation within Zhao's rebellion. Besides a pastiche of Romanticism, Zhao's Ballade in Db Major also demonstrates impressionistic quartal chords. The musicologist Fan explained that the themes in a pentatonic scale were furnished well with Western quartal. ${ }^{52}$ A continuous connection consisting of quartal chords in mm. 82-84 creates a soundscape of sorrow and loneliness, under the dynamic of $p p$ (Example 9).

51 Xiaosheng Zhao, interview, October 31, 2016, Shanghai, China; translation by the authors.

52 Zuyin Fan, "Siwudu Jeigou yu Erdu Jiegou de Hesheng Fangfa," ["The Harmonic Methodology for the Structure of fourth, fifth and second intervals"], Huangzhong-Journal of Wuban Music Conservatory, no. 2 (2002): 3-14. 


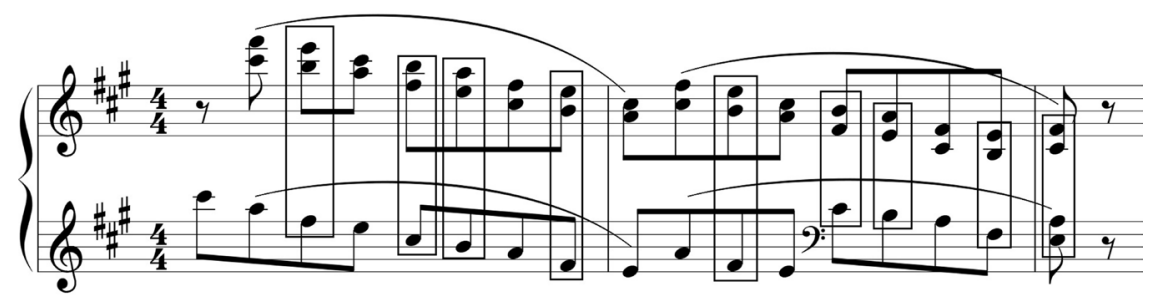

Example 9: The application of quartal chords in Ballade in Db Major, mm. 82-84.

The two works seemingly form a contrasting dualism regarding Zhao claim that the Ballade in Db Major represents the West and the Ballade in $D$ Gong Scale represents the East. However, after conducting the harmonic analysis, no such obvious distinct features were observed in both works. For example, it may be argued that the F\# minor mode in mm. 98-100 of Ballade in Db Major (Example 10) suggests a heptatonic scale of B Gong scale, revealing a combination of pentatonic melody comprising chordal movement with second-degree descending. Conversely, Western harmonic writing is employed in the coda of Ballade in D Gong Scale (mm. 257-273). This passage in Ballade in D Gong Scale shows a pastiche of harmonic pattern identical to Chopin's Polonaise-Fantaisie in Ab Major, Op. 61 (Example 11) and a hidden melody in the upper register in the manner of qingyue ${ }^{53}$ of D Gong scale.

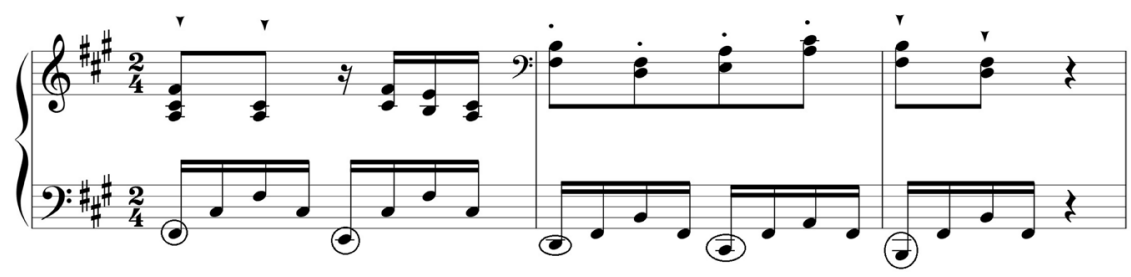

Example 10: The combination of Chinese and Western harmonies in Ballade in Db Major, mm. 98-100.

Additionally, another passage at mm. 76-80 of Ballade in D Gong Scale reveals a synthesis of Chinese and Western harmony (Example 12), wherein the accompaniment shows a linear harmony with the pitches of $\mathrm{B}, \mathrm{E}, \mathrm{F} \#, \mathrm{G} \#$,

53 According to the Chinese traditional theory, a pentatonic scale is allowed to add two additional tones to establish a heptatonic scale. If a pentatonic scale is added by bianyin of bianzhi and biangong, the heptatonic scale would be called yayue (雅乐). Similarly, a pentatonic with bianyin of qingjue and biangong constitutes qingyue (清乐), and the assembling of a pentatonic plus bianyin of qingjue and run is regarded as yanyue (燕乐). 


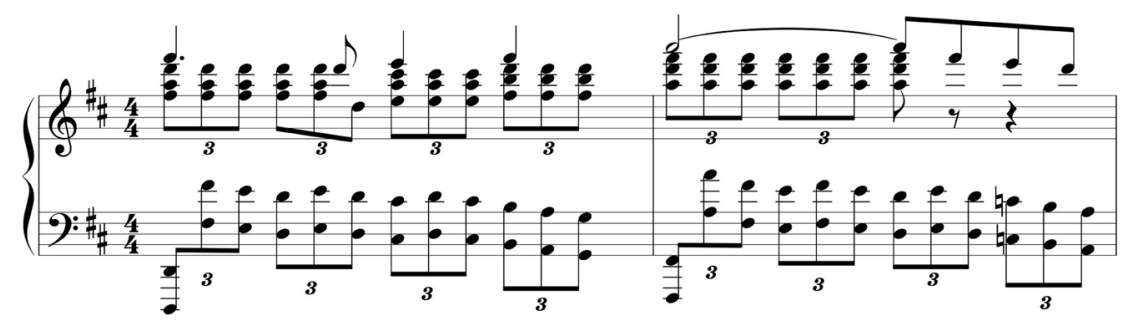

Example 11: The combination of Chinese and Western harmonies in Ballade in D Gong Scale, mm. 257-258.

and A under the A Gong scale. Simultaneously, a harmonic progression of $\mathrm{E}-\mathrm{G} \#-\mathrm{B}-\mathrm{D}$ to $\mathrm{A}-\mathrm{C} \sharp-\mathrm{E}$ at $\mathrm{mm}$. $79-80$ forms a functional resolution $\left(\mathrm{V}_{7} \rightarrow \mathrm{I}\right)$ typical of Western harmony.
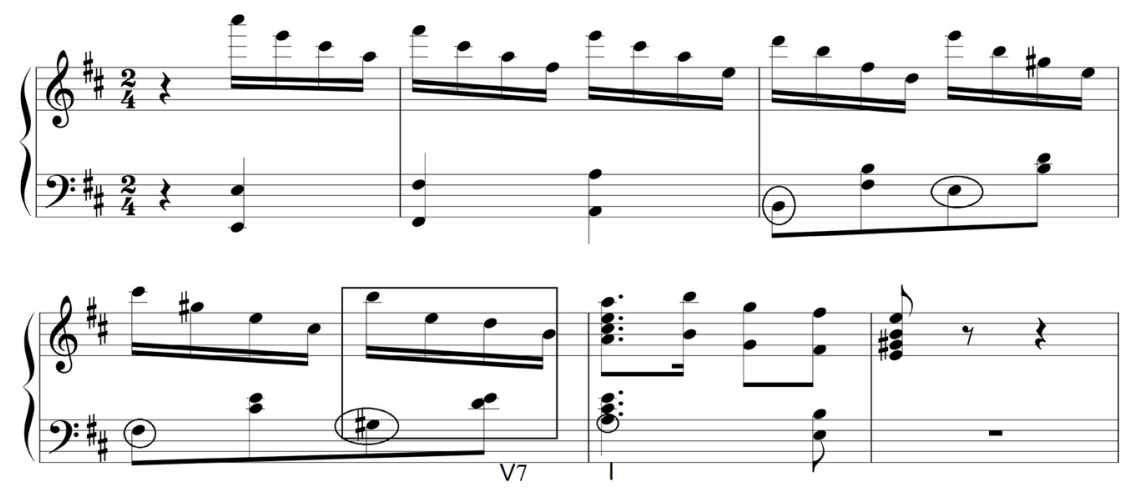

Example 12: The combination of Chinese and Western harmonies in Ballade in D Gong Scale, mm. 76-80.

\section{Conclusion}

The exploration of Zhao's two piano ballades along with a conversation with the composer revealed significant complex insights into the poiesis state of the composer during the composition of the two works during the harsh time of the Cultural Revolution. We concluded that the distinction between the two ballades, according to that of the composer's original intention, is rather ambiguous (Table 4).

The two ballades were written in the same year but present different thoughts and purposes. Due to the death of his father, Zhao held a personal grudge against the Cultural Revolution. He had to hide his feelings of antagonistic rage, fear, and devastation over the death of his father. Thus, Zhao 
Table 4: Comparison between Ballade in Db Major and Ballade in D Gong Scale

\begin{tabular}{|c|c|c|c|}
\hline & \multirow[b]{2}{*}{ Ballade in Db Major } & \multirow[b]{2}{*}{ Ballade in D Gong Scale } \\
\hline & & & \\
\hline \multicolumn{2}{|c|}{$\begin{array}{c}\text { Year of completion as } \\
\text { published }\end{array}$} & 1977 & 1976 \\
\hline \multicolumn{2}{|c|}{ Actual year of completion } & 1976 & 1976 \\
\hline \multirow{4}{*}{$\begin{array}{l}\text { Musical } \\
\text { form }\end{array}$} & General & $\begin{array}{l}\text { Compound ternary } \\
\text { form } \\
\end{array}$ & Compound ternary form \\
\hline & First part & Western binary form & $\begin{array}{c}\text { Simple ternary form, but the first } \\
\text { section is in the Chinese form of } \\
\text { qi, cheng, zhuan, and he }\end{array}$ \\
\hline & Second part & Chinese variation & Western trio \\
\hline & Third part & $\begin{array}{l}\text { Western strophic } \\
\text { form }\end{array}$ & Similar with the first part \\
\hline \multicolumn{2}{|c|}{ Tempo range } & $d=46-100$ & $d=90-156$ \\
\hline \multicolumn{2}{|c|}{ Rhythmic pattern } & $\begin{array}{l}\text { Chopin's rhythmic } \\
\text { pattern }\end{array}$ & $\begin{array}{c}\text { Traditional Chinese gong and } \\
\text { drum rhythmic pattern of } \\
\text { "1-4-7" }\end{array}$ \\
\hline \multicolumn{2}{|c|}{ Tonality } & $\begin{array}{l}\text { Western major and } \\
\text { minor keys }\end{array}$ & Pentatonic scale \\
\hline \multicolumn{2}{|c|}{ Harmony } & $\begin{array}{l}\text { Western theory with } \\
\text { Chinese elements }\end{array}$ & $\begin{array}{c}\text { Chinese theory with Western } \\
\text { elements }\end{array}$ \\
\hline
\end{tabular}

took a personal and political stance in his composition of Ballade in Db Major, revealing his suppressed hostility towards the Cultural Revolution through his music. The use of "rural" aesthetics in the Ballade in D Gong Scale may be ridiculed, but at the same time, this work might have masked Zhao's antagonism.

Zhao intentionally compared these two ballades with sarcasm, and these works present an ironic interplay between what was legitimate and illegitimate to the Red Guards. However, the two ballades reflect the compositional styles of Chinese composers of that time. Similar to what Liu observed, Chinese new music of that time has a common trait of borrowing musical elements from traditional forms and pentatonic scale with copies of Western music and style. ${ }^{54}$ Therefore, Zhao's ballades conform to the compositional trends of their time and these ballades show that Zhao's early works are not as mature as compared to his later works. On the other hand, although Zhao was hostile towards the rules of creating artistic works during the revolution, his aesthetical background as a Chinese composer with years of training in Western art music led to a writing style in his ballades that nationalistically conforms to the rules

54 Ching Chih Liu, "Copyright, Imitating and Transplanting: Three Stages in the Development of New Music in China,” Lingnan Journal of Chinese Studies 1, no. 1 (1999): 571-623. 
set under the revolution. However, this nationalistic style contradicted with his original intention stated during his interviews.

The political upheaval and pressure during the Cultural Revolution resulted in a trend of musical output that comprised an emergence of traditional instrumental adaptations, borrowed ethnic musical elements, and works based on the Model Opera. In spite of the apparent conformance of Zhao's two ballades to the nationalistic style, these works reveal a hidden musical polemic of Zhao. We witnessed in the analysis how the phenomenon of China's Cultural Revolution with its Laogai system and its association of the West with modernity heavily influenced the composers and their works. In this case, Zhao's ballades reveal illustrative examples of this phenomenon. The chaos and the purge of musicians during the Cultural Revolution resulted in an expression of political ambivalence in Zhao's works. Thus, his two ballades display a contradictory theme with the use of Chinese elements in the Western pastiche Ballade in Db Major, and the use of Western elements in the Chinese nationalistic piece Ballade in D Gong Scale. To summarize, this paper reveals the controversial role of Western art music in the history of music in China during the Cultural Revolution. In addition, signs of unintended allegiance towards the faction were discovered in Zhao's two ballades, which somehow won over the composer's political infighting and vengeful hostility toward the Cultural Revolution due to his father's death. Thus, this finding reflects an eerie outcome of power seizure and possession of the composer's poiesis, regardless of his will.

\section{Bibliography}

Beyer, Anna Cornelia. International Political Psychology: Explorations into a New Discipline. London: Macmillan Publishers Ltd, 2017.

Chang, Chun Ya. "The Yellow River Piano Concerto: A Pioneer of Western Classical Music in Modern China and Its Socio-Political Context." DMA diss., University of Alabama, 2017.

Chi, Robert. "The March of the Volunteers: From Movie Theme Song to National Anthem." In Re-envisioning the Chinese Revolution: The Politics and Poetics of Collective Memories in Reform China, edited by Ching Kwan Lee and Guobin Yang, 217-244. Washington, D.C.: Woodrow Wilson Center Press, 2007.

Cushing, Lincoln, and Tompkins Ann. Chinese Posters: Art from the Great Proletarian Cultural Revolution. San Francisco: Chronicle Books LLC, 2007.

D'Anieri, Paul. International Politics: Power and Purpose in Global Affairs. Boston: Cengage Learning, 2011.

Fan, Zuyin. “Siwudu Jeigou yu Erdu Jiegou de Hesheng Fangfa.” [“四五度结构与二度 结构的和声方法” / “The Harmonic Methodology for the Structure of Fourth, Fifth and Second Intervals."] Huangzhong-Journal of Wuban Music Conservatory, no. 2 (2002): 3-14.

$\mathrm{Hu}$, Angang. Mao and the Cultural Revolution: Volume 1 - Mao's Motivation and Strategy. Honolulu, Hong Kong, Beijing and Singapore: Silkroad Press, 2017. 
Huang, Qiang. “Lun Qichengzhuanhe.” [“论起承转合” / “Discussion of qi, cheng, zhuan and he."] Jinyang Xuekan, no. 3 (2010): 124-129.

Jian, Guo, Song Yongyi, and Zhou Yuan. Historical Dictionary of the Chinese Cultural Revolution. Maryland, Toronto and Oxford: The Scarecrow Press, 2006.

Judd, Ellen R. "Perspective Dramatic Theory of Cultural Revolution." In Drama in the People's Republic, edited by Constantine Tung and Colin Mackerras, 94-118. Albany: State University of New York, 1987.

Kang, Le. “The Development of Chinese Piano Music.” Asian Culture and History 1, no. 2 (2009): 18-33.

Kraus, Richard Curt. Pianos and Politics in China: Middle-Class Ambitions and the Struggle over Western Music. New York and Oxford: Oxford University Press, 1989.

Kraus, Richard Curt. "Policy Case Study: The Arts." In Politics in China: An Introduction, edited by William Joseph, 371-392. New York: Oxford University Press, 2019.

Lee, Hong-Yung. The Politics of the Chinese Cultural Revolution: A Case Study. Berkeley: University of California Press, 1978.

Leung, Cynthia B., and Yiping Wang. "Influences of the Cultural Revolution on Chinese Literacy Instruction." In Perspectives on Teaching and Learning Chinese Literacy in China, edited by Cynthia B. Leung and Jiening Ruan, 49-60. London: Springer, 2012.

Li, Jiti. Zhongguo Yinyuejiegou Fenxi Gailun. [中国音乐结构分析概论 / General Analysis of Chinese Music Structure.] Beijing: Central Conversotary of Music Press, 2004.

Liang, Maochun. "Wenhua Dageming Shiqi de Yinyue - We Wenge Jieshu Ershinian er Zuo.” “文化大革命”时期的音乐——为文革结束二十年而作” / “The Music in Cultural Revolution - For the Twenty-Year Temination of Cultural Revolution."] Jiao Xiang -Journal of Xi'an Conservatory of Music, no. 4 (1996): 17-21.

Liu, Ching-Chih. A Critical History of New Music in China. Hong Kong: The Chinese University Press, 2010.

Liu, Ching-Chih. "Copyright, Imitating and Transplanting: Three Stages in the Development of New Music in China.” Lingnan Journal of Chinese Studies 1, no. 1 (1999): 571-623.

Liu, Xizai. Yigai (Jingyi Gai). [艺概(经义概) / Generality of Arts (Generality of Jingyi).] Shanghai: Shanghai Ancient Books Publishing House, 1978.

Lu, Guang. "Modern Revolutionary Beijing Opera: Context, Contents and Conflicts." PhD diss., Kent State University, 1997.

Lu, Xing. Rhetoric of the Chinese Cultural Revolution: The Impact on Chinese Thought, Culture, and Communication. Columbia, SC: University of South Carolina Press, 2004.

Maine, Rachel J. "Comparative Repression: Examples of Musical Repression by Hitler, Stalin, and Mao.” Master's thesis, Baylor University, 2006.

Mao, Zedong. Quotations from Chairman Mao Tse-Tung [Little Red Book]. Peking: Foreign Language Press, 1966.

Melvin, Sheila, and Cai Jindong. Rhapsody in Red: How Western Classical Music Became Chinese. New York: Algora Publishing, 2004.

Mittler, Barbara. "Chinese New Music as a Politicized Language: Orthodox Melodies and Dangerous Tunes." In Language and Politics in Modern China, edited by Jeffery Wasserstrom and Sue Tuohy, 1-22. Bloomington, Indiana: Indiana University, 1996.

Mittler, Barbara. Dangerous Tunes: The Politics of Chinese Music in Hong Kong, Taiwan, and the People's Republic of China since 1949. Wiesbaden: Harrassowitz, 1997.

Mittler, Barbara. "Cultural Revolution Model Works and the Politics of Modernization in China: An Analysis of 'Taking Tiger Mountain by Strategy'." The World of Music 45, no. 2 (2003): 53-81. 
Moskowitz, Marc L. Cries of Joy, Songs of Sorrow: Chinese Pop Music and Its Cultural Connotations. Honolulu: University of Hawai'i Press, 2010.

Pang, Laikwan, Clark Paul, and Tsai Tsan Huang. Listening to China's Cultural Revolution: Music, Politics, and Cultural Continuities. Hampshire: Palgrave MacMillan, 2016.

Persichetti, Vincent. Twentieth Century Harmony. London: Faber and Faber, 1961.

Rao, Nancy Yunwha. "Hearing Pentatonicism through Serialism: Integrating Different Traditions in Chinese Contemporary Music.” Perspectives of Nerw Music 40, no. 2 (2002): 190-231.

Schoenberg, Arnold. Theory of Harmony. Translated by Roye Carter. London: Faber and Faber, 1911.

Sullivan, Larry E. The Sage Glossary of the Social and Behavioral Sciences. California: Sage Publications, 2009.

Sullivan, Michael. "The Politics of Conflict and Compromise." In China Since the 'Gang of Four', edited by Bill Brugger. London: Routledge, 1980.

Tan, Lek Horm. "Fou Tsong: I Wept for China." Index on Censorship 8, no. 89 (2007): 20-21.

Wang, Anguo. “'Xinchao'Yinyue - Yiduan Teding de Lishi Wenhua Guocheng.” ““新潮”音 乐一一段特定的历史文化过程” / “New Wave’ Music - A Special historal and cultural process."] Literature E' Art Studies, no. 1 (1988): 62-72.

Wang, Zhenya. Zhongguo Zuoqu Jifa de Yanbian. [中国作曲技法的衍变 / The Dervelopment of Chinese Compositional Techniques.] Beijing: Central Conservatory of Music Press, 2004.

Wemheuer, Felix. A Social History of Maoist China: Conflict and Change, 1949-1976. New York: Cambridge University Press, 2019.

Xu, Guohui. Model Operas E the Politics of the Great Proletarian Cultural Revolution. Taibei: Showwe Publisher, 2019.

Xue, Ke, and Loo Fung Ying. "Reminiscing Crashing Waves and Romanticism in Zhao Xiaosheng's Fisherman Song." Malaysian Journal of Performing and Visual Arts 3 (2017): 7-30.

Xue, Ke, and Loo Fung Ying. "Transcoding the I Ching as Composition Techniques in Chou Wen Chung, Zhao Xiaosheng and Chung Yiu Kwong." Revista Música Hodie 19 (2019): 1-29. https://doi.org/10.5216/mh.v19.52739.

Yung, Bell. "Model Opera as Model from Shajiabang to Sagaban." In Popular Chinese Literature and Performing Arts in the People's Republic of China 1949-1979, edited by Bonnie S. McDougall, 144-164. Berkeley: University of California Press, 1984.

Zhang, Bin. "Huang Anlun Xuqu yu Wuqu de Chuangzuo Jingguo yu Mingming Qianhou.” “黄安伦序曲与舞曲的创作经过与命名前后” / “The Compositional Procedure and Title Source of Huang Anlun's Overture and Dance."] Journal of Tianjin Conservotary of Music (Sounds of Nature), no. 3 (2016): 33-51. 


\section{POVZETEK}

\section{Kulturna revolucija in politična ambivalenca v dveh baladah za klavir Žaa Šaošenga}

V času kitajske kulturne revolucije (1966-1976) je bil glasbeni razvoj na Kitajskem močno spolitiziran zaradi vodilne doktrine predsednika Maa in njegovega tabora - glasbeni repertoar tega obdobja sestavljajo revolucionarne opere ter revolucionarne in domoljubne pesmi. Sistem laogai in revolucionarna dela so močno vplivala na komponiranje nove glasbe, ki je nastajala v skladu s politično propagando revolucije. Čistka desničarjev, vključno z glasbeniki, ki se niso podredili vladavini Komunistične partije Kitajske, je v tistem obdobju pripeljala do vdanosti glasbe partijskemu modelu ustvarjanja umetniških del. Skladatelja Žaa Saošenga, katerega oče je bil med enajstimi profesorji Šanghajskega konservatorija za glasbo, ki so bili žrtve revolucionarne čistke, je preplavil obup. Potlačil je svojo sovražnost do novega režima in napisal dve baladi za klavir: Balado v Des-duru in Balado v D pentatonski gong lestvici. Članek prvič razkriva ozadje in dolgo skrivani pravi datum nastanka balade, in dejstvo, da je bila le-ta nezakonit glasbeni pasticcio zahodne klasične glasbe, ki je bila v času revolucije prepovedana. Prispevek prikazuje, kako se Žaovo trpljenje, strah, sarkazem in odpor odražajo v njegovih baladah. Preplet s čustvenim lahko razumemo kot razlog za politično in umetniško ambivalenco v njegovih dotičnih klavirskih baladah. Baladi sta v članku obravnavani kot reprezentativni deli kulturne revolucije.

\section{ABOUT THE AUTHORS}

KE XUE (shengguadanzi@163.com) is an Associate Professor at College of Humanities, Beibu Gulf University. Her research interests include Chinese contemporary music, Chinese piano music and performance practice. Her publication include research on Zhao Xiaosheng's piano compositions, Zhao Xiaosheng's Tai Chi composition system and Chinese contemporary piano music.

FUNG YING LOO (loofy@um.edu.my) is an Associate Professor at the Department of Music, Faculty of Creative Arts, University of Malaya. Her research interests include performance practice, cultural musicology and musical theatre. Her publication includes Malaysian Chinese music, Taichi and its application on piano playing skills, and musical theatre.

FUNG CHIAT LOO (fungchiat@hotmail.com) is an Associate Professor at the Department of Music, University Putra Malaysia. Her research interest includes piano performance practice and musical theatre. Her publication includes studies on performance practice of Messiaen and Malaysian musical theatre.

XIAOHANG WANG (wangxiaohang11@163.com) is an Associate Professor at Beibu Gulf University. His research interest includes Chinese historical and political study, Chinese music culture, and audio frequency analysis of modern piano music. 


\section{O AVTORJIH}

KE ŠUE (shengguadanzi@163.com) je izredna profesorica na Kolidžu za humanistiko Univerze Beibu Gulf (College of Humanities, Beibu Gulf University). Raziskovalno se posveča sodobni kitajski glasbi, klavirski glasbi na Kitajskem in uprizoritvenim praksam. Med drugim je objavljala o klavirskih skladbah Žaa Šaošenga, njegovi skladateljski tehniki Taj $\check{C} i$ in sodobni kitajski klavirski glasbi.

FUNG JING LU (loofy@um.edu.my) je izredna profesorica na Oddelku za glasbo Fakultete za ustvarjalne umetnosti na Univerzi Malaya. Raziskovalno se posveča uprizoritvenim praksam, kulturni muzikologiji in glasbenemu gledališču. Objavljala je o malezijsko-kitajski glasbi, Tajčju in njegovi uporabi pri učenju igranja klavirja in o glasbenem gledališču.

FUNG ŠIAT LU je izredna profesorica na Oddelku za glasbo Univerze Putra Malaysia. Raziskovalno se posveča klavirskim uprizoritvenim praksam in glasbenemu gledališču. Objavila je raziskave o izvajalski praksi Messiaena in o malezijskem glasbenem gledališču.

ŠAOHANG VANG (wangxiaohang11@163.com) je izredni profesor na Univerzi Beibu Gulf. Raziskovalno se posveča kitajskim zgodovinskim in političnim vedam, kitajski glasbeni kulturi in avdio frekvenčni analizi sodobne klavirske glasbe. 